\title{
A Constructivist Approach to a Mobile Learning Environment
}

\author{
Dawood S. Al Hamdani \\ Sohar University, Sohar \\ The Sultanate of Oman
}

\begin{abstract}
Information is growing rapidly due to advances in learning and communication technologies. In the past, books and educators were the most frequent sources of information. Nowadays, there are many resources through which information can be accessed ranging from PCs, PDAs and Mobile Devices. In Oman in General, and at Sohar University in particular, such devices are widely available and are used constantly by students. In this paper, we look at how students use smart devices to enhance their learning capabilities. In order to so , the paper presents a case study which was carried out using resource based learning activities over a period of four to eight weeks to teach communicative language course to fourth year students at Sohar University. Moreover, the paper will also discuss how to develop innovative pedagogies using mobile technologies in order to enhance teaching and learning in higher education and how to make recommendations for teaching, and staff professional development.
\end{abstract}

\section{Keywords}

Mobile learning, constructivism, active learning.

\section{INTRODUCTION}

WITH advances in learning technology and communication, information is growing rapidly. In the past, books and teachers were the most frequent sources of information; nowadays there are many resources through which information can be accessed from PCs as well as smartphones, and other mobile devices. Figure 1 shows a class attendance list with types of smart devices the students possess. It clearly indicates that there is scope for using such smart devices as a cognitive tool to promote higher order thinking skills. This paper commences by introducing, defining mobile learning, and designing a constructivist mobile learning environment. It will present and discuss our case study in mobile learning.

\section{MOBILE LEARNING}

Mobile learning can be defined as the use of mobile devices as mediator in the process of learning and teaching [1], that is to say the use of mobile devices as mediator in the process of learning and teaching. This can be seen as both: learning from the mobile and learning with the mobile. The term learning from mobile implies the use of smart devices as a tool to deliver learning materials specially designed for a specific learning purpose. The learning with mobile means the use of mobile devices as a cognitive tool to promote higher order thinking skills such as analyzing, evaluating and creating [2].

Smart devices are neutral to teaching and learning theories. They can be used with traditional learning theories such as behaviorism, and new learning theories such as constructivism. For example, in the field of behaviorism which focuses on repetition in the curriculum content, studies show drill and practice learning materials have a positive role in helping students to learn[3], [4]. However, many researchers in technology, as well as the author's view is the optimum utilization of mobile devices in the development of higher thinking skills and problems solving.

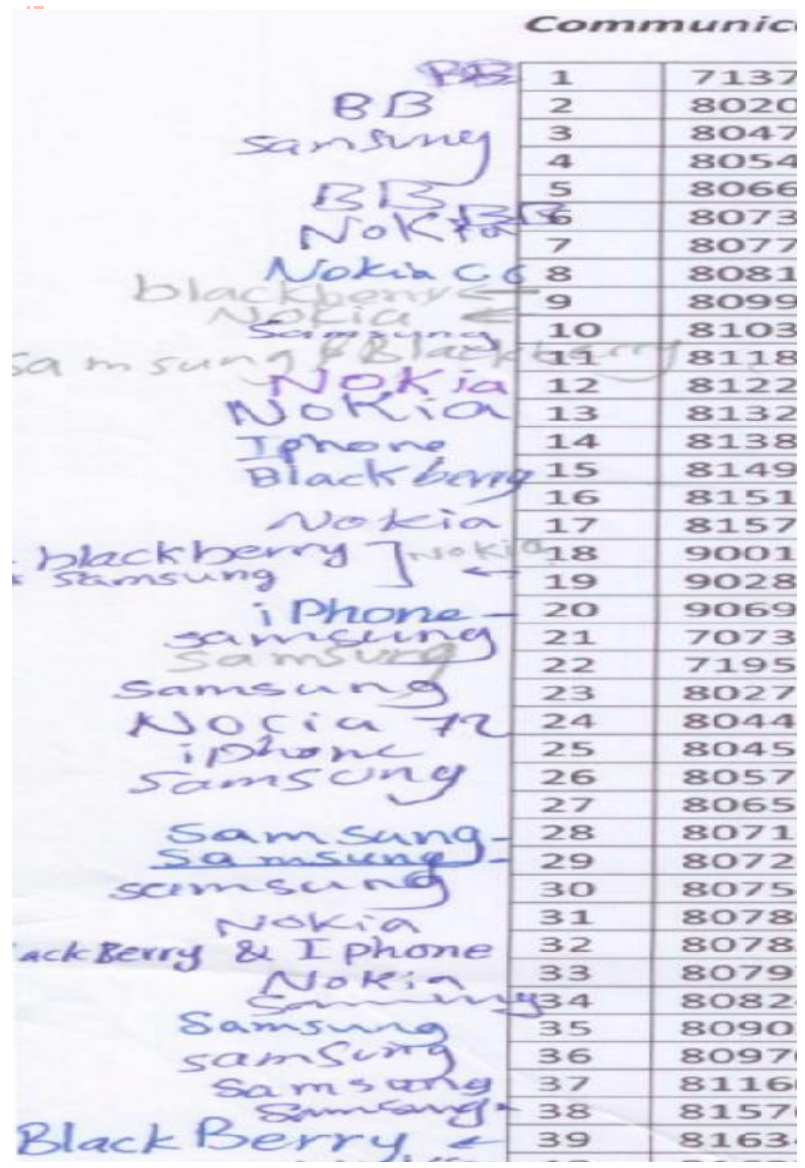

Figure 1: A student attendance class list showing all

types of smartphones.

Strommen and Lincolon state "The key to success lies in finding the appropriate points for integrating technology into a new pedagogical practice (constructivism) so that it supports the deeper, more reflective self-directed activity children must use if they are to be competent adults in the future."[5]. Technology integration can effectively support constructivism [6]. We presumes that constructivism is the proper theory for the activation of the role of technology in the learning process, and set technology in the right direction to apply the principles of constructivist learning. Despite the significant 
potential of mobile technologies employed as powerful learning tools in higher education, their current use appears to be predominantly within a didactic, teacher-centered paradigm, rather than a more constructivist environment. The purpose of this paper to shed lights on the practice of using of mobile phones as a cognitive tool to enhance students' learning in using constructivist approach [7].

\section{CASE STUDY}

The aim of this case study is to develop innovative pedagogies using mobile technologies. Our intention is to enhance teaching and learning in higher education and to make further recommendations for teaching staff professional development. Specifically this study looks at the usage of mobile devices by the students to improve their teaching and learning by implementing resource based activities over a period of 4-8 weeks by teaching a communicative language teaching course for forth year English Teachers at Sohar University in the Sultanate of Oman. Fourty students participated in this case study.

\section{THE COUNTRY AND THE UNIVERSITY CONTEXT}

Oman, with a population of only two million people is a small but nonetheless progressive and developing nation in the Middle East. With fossil fuel reserves dwindling in the foreseeable future, the government has decided to strive to attain a knowledge-based economy, and to reduce dependence on the current resource based economy. By far the biggest factor currently holding the country back is the lack of a well-grounded educational system . The public school system in the country has only been in existence for the past forty years. Prior to that Oman only had three primary schools.

There are universal primary and secondary education for both boys and girls. University attendance is in the increase. Currently Sohar University has over five thousand students registered in Diploma, Bachelor and Masters programs. They spread over five faculties staffed by more than two hundred and seventy lecturers and professors. $70 \%$ of our students are young women seeking to gain their rightful place in the new society that Oman is building.

Technology is in its way to be integrated into teaching and learning at Sohar University. Moodle, the most popular Learning Management Systems (LMS) used under the name of SULMS ( Sohar University Leaning Management System) - The tool is recommended to teachers to used in their teaching. Most students at Sohar University have computers/laptops and have at least a mobile device (smart phone). For example, the snap shot survey for mobile device ownership by the students in the study shows that twenty students own one mobile, sixteen own two mobiles and ten have three mobiles. However, prior to this study, mobiles usages are not supported during classroom teaching sessions due to the absence of pedagogies, instructional method, and the lack of ability to integrate technologies into teaching.

\section{CONSTRUCTIVIST-MOBILE LEARNING ENVIRONMENT 5.1 Method of instruction: constructivist approach}

Constructivism, according to Vygotsky maintains that knowledge is constructed by the individual from within rather than being transmitted to the learner from another outside source. Therefore, learning is seen as a process of actively constructing knowledge by integrating experiences into the learners' prior knowledge; the learner plays an active role in building his/her knowledge. The founder of social constructivism emphasizes the importance of the interaction with the others such as peer, teachers and parents to build knowledge. He also emphasizes the need for tools such as language and computer to mediate knowledge construction [8]. The best learning occurs in the middle of social interaction. The adoption of constructivist approach in richtechnology environment, promotes the full potential of technologies in enhancing learning [9]. The following section sheds light on technologies that serve best the constructivist approach.

The proposed constructivist-mobile learning environment is characterized by new roles of teacher and learner, specifically designed for learning activities and uses the mobile device as a medium. Mobile devices allow learner opportunities for collaboration in the creation of products and for sharing them among their peers [10]. The advantages of mobile learning can be gained, through collaborative, contextual, constructionist and constructivist learning environments [11].

\subsection{New roles for the teacher and the learners}

Constructivist-mobile learning environment imposes new roles for the teacher. Unlike traditional "top-down" teaching, Vygotsky would advocate a bottom-up teaching approach where the teacher facilitates, as opposed to directs, what and how students learn concepts both in and out of the classroom. In the learning setting with the use of mobiles, the teacher should contribute a major role in establishing the learning environment for her/his students. Teacher' role is as facilitator, coacher and co-learner. Her/his responsibility is to help and guide learners throughout their knowledge acquisition. Such a role of providing guidance for learners is, according to Vygotsky, to motivate learners to excel beyond their current skills level (i.e. activating learners' zone of proximal development.); learners are viewed as knowledge constructors [8].

\subsection{Learning activities}

The useable knowledge is best gained in learning environments which feature the following characteristics:

- authentic contexts that reflect the way the knowledge will be used in real-life,

- $\quad$ authentic activities that are complex, ill-defined problems and investigations,

- $\quad$ access to expert performances enabling modeling of processes,

- multiple roles and perspectives providing alternative solution pathways,

- collaboration allowing for the social construction of knowledge,

- opportunities for reflection involving metacognition,

- opportunities for articulation to enable tacit knowledge to be made explicit,

- coaching and scaffolding by the teacher at critical times and 
- authentic assessment that reflect the way knowledge is asses in real life [12].

The activities used in the practice depict some of the abovementioned characteristics of authentic learning activities. The activities afford the learners to interact with the e-learning materials and interact with the others in cooperative manner seeking knowledge. The activities promote learners to use the cognitive thinking skills, especially the higher ones, as in Bloom's Taxonomy and enhance their motivation. Riischoff maintains that "learning activities are always social activities with learners cooperating and working together." [13]

\subsection{Instructional events design}

The design of learning environment events was based on constructivist principles and with the use of activities as above mentioned. Jonassen proposed that knowledge construction may best be facilitated by constructivist learning environments that:

- provide multiple representations of reality, which avoid oversimplification

- focus on knowledge construction, not reproduction

- present authentic tasks (contextualising rather than abstract instruction)

- provide real world, case based learning environments rather than pre-determined instructional sequences

- $\quad$ foster reflective practice

- enable context- and content-dependent knowledge construction

- support collaborative construction of knowledge [14]

The following brief events of instruction were implemented in the practice. In each session, the participants, first, were introduced to the session topic; divided into groups. Each group was assigned a task separately. The students were given time to discuss the tasks among themselves in groups and the instructor provided guides and clarification, when needed. The students brainstormed required information to do the activities and used their mobile phones while performing tasks. At the end of each session, the students presented and shared their findings with class and discussion was elicited. The works were posted in SULMS (Moodle), as resources to be used in future.

\section{THE PRACTICE DESIGN AND INSTRUMENTATION}

To gain a clearer picture of how mobile phone was used in this practice as a tool to enhance students' learning in Communicative Language Teaching (CLT) course, a 5-point Likert scalequestionnaire was developed to provide information on the frequency of the following themes:

1. Students' ICT backgrounds

2. Mobile phones use in classroom and out classroom

3. Mobile phones promote of thinking skills

4. Mobile to support cooperative work

5. Problems faced while using Mobile phones

\section{RESULTS OF THE CASE STUDY}

This section shows how students use their own mobiles inside classroom session and outside classroom for the purpose of learning their course materials. It looks at the findings of the above-mentioned themes.

\subsection{Students' ICT backgrounds}

\subsubsection{Students' ICT skills}

The participants seem to have good commands of ICT skills. For examples, as in table (1), Nineteen (19) of them have both ICT3 certificates and computer course, Eleven (11) of them have ICT3 certificates, Eight (8) of them have computer course, see the table for more detail.

TABLE 1. Students' Skills

\begin{tabular}{|c|c|}
\hline ICT Skills & No of Students \\
\hline ICT3 and Computer courses & 19 \\
\hline ICT3 & 11 \\
\hline Computer Courses & 8 \\
\hline ICT3 and ICDL & 1 \\
\hline Nothing & 1 \\
\hline
\end{tabular}

\subsubsection{Use of Social Interaction Technologies}

The table (2) shows that the participants are familiar with some social interaction technologies such as FaceBook and email. For examples, all of the students have emails, 25 of them have FaceBook accounts and 13 of them have Twitter Accounts.

Table 2. Social interaction technologies

\begin{tabular}{|c|c|c|c|c|c|}
\hline & Blog & FaceBook & Twitter & Website & Email \\
\hline $\begin{array}{c}\text { No of } \\
\text { students }\end{array}$ & 1 & 25 & 13 & 4 & 40 \\
\hline
\end{tabular}

\subsubsection{Ownership of Mobile Phone}

As mentioned in this paper, 40 students participated in this exercise. Twenty the students own one mobile, sixteen own two mobiles and four students have three mobiles, However, mobiles usages are not supported during classroom sessions. The table below (table 3 ) shows the bands of mobile devices owned by the participants.

Table 3. Ownership of mobile phone

\begin{tabular}{|c|c|c|c|c|}
\hline Samsung & Nokia & BlackBerry & iphone & Sony \\
\hline 22 & 20 & 11 & 4 & 2 \\
\hline
\end{tabular}

\subsection{Mobile phones use in classroom and out classroom}

Overall, respondents were overwhelmingly used their mobile phones in their learning to do the assigned course activities. Table (4) and table (5) show that most use of mobile phones is to: search for information, access dictionary and look for 
vocabulary, and less use to read articles and access SULMS (Moodle). On average, the students used their mobile phones to translate texts and check their spelling. It is interesting to note that there is no significant difference between in-class use and out-class use of mobiles, see table (6).

Table 4. Mobile phone used in the classroom

\begin{tabular}{|c|c|c|}
\hline In classroom use items & Mean & S. D. \\
\hline Read articles & 2.78 & 1.14 \\
\hline $\begin{array}{c}\text { Access SULMS (Moodle) } \\
\text { Translate texts from Arabic to English } \\
\text { and vice versa. }\end{array}$ & 2.93 & 1.33 \\
\hline Check spelling & 3.08 & 1.37 \\
\hline Access information & 3.7 & 1.32 \\
\hline Look for vocabulary & 3.78 & 1 \\
\hline Search for information & 3.95 & 1.13 \\
\hline Access dictionary & 4.07 & 1.02 \\
\hline
\end{tabular}

Table 5. Mobile phones use outside classroom

\begin{tabular}{|c|c|c|}
\hline Outside classroom Items & Mean & S. D. \\
\hline Access SULMS (Moodle) & 2.75 & 1.3 \\
\hline Read articles & 3.05 & 1.3 \\
\hline $\begin{array}{c}\text { Check spelling } \\
\text { Translate texts from Arabic to English } \\
\text { and vice versa. }\end{array}$ & 3.53 & 1.22 \\
\hline $\begin{array}{c}\text { Access information } \\
\text { Look for vocabulary }\end{array}$ & 3.72 & 1.32 \\
\hline Access dictionary & 4.05 & 0.99 \\
\hline Search for information & 4.1 & 0.98 \\
\hline
\end{tabular}

Table 6. Difference in use

\begin{tabular}{|l|c|c|l|}
\hline Paired Samples Test & & & \\
\hline $\begin{array}{l}\text { In class- Out class } \\
\text { Mobile Use }\end{array}$ & t & df & Sig. (2-tailed) \\
\cline { 2 - 4 } & -0.309 & 39 & 0.759 \\
\hline
\end{tabular}

\subsection{Mobile phones to promote of thinking}

\section{skills}

The participants do think that mobile phones some extent have a role in helping them with thinking skills, as show in table (7) mostly helped them in selecting the right information.

Table 7. Mobile phones and Thinking skills

\begin{tabular}{|c|c|c|}
\hline Thinking skills Items & Mean & S. D. \\
\hline To rearticulate (paraphrase) information & 3 & 1.11 \\
\hline To critique what is available on the net & 3.23 & 1.14 \\
\hline To remember information better & 3.4 & 1.08 \\
\hline To organize my information/answer & 3.45 & 1.24 \\
\hline To use the acquired information in activities & 3.47 & 1.06 \\
\hline To scan and scam for needed information & 3.58 & 1.01 \\
\hline To memorize something and repeat it. & 3.6 & 1.15 \\
\hline To understand ideas/concepts better & 3.68 & 0.94 \\
\hline To produce a good work & 3.7 & 0.94 \\
\hline To select the right information & 3.75 & 1.06 \\
\hline
\end{tabular}

For example, table (8) shows that most students see the mobile phones have helped them memorizing and repeating materials; memorization and reparation are low thinking skills.

Table 8. Mobile phones and memorization

\begin{tabular}{|l|l|l|l|l|l|}
\hline $\begin{array}{c}\text { To memorize } \\
\text { something and } \\
\text { repeat it. }\end{array}$ & $\begin{array}{c}\text { Not at } \\
\text { all }\end{array}$ & $\begin{array}{c}\text { A } \\
\text { little }\end{array}$ & Some & $\begin{array}{c}\text { Quite } \\
\text { a bit }\end{array}$ & $\begin{array}{c}\text { Very } \\
\text { Much }\end{array}$ \\
\hline No of response & 1 & 7 & 10 & 11 & 11 \\
\hline
\end{tabular}

In addition, table (9) shows most students indicate that mobile phones contributed to produce good works for their activities. The ability to produce a good work is considered to be higher order skill.

Table 9. Mobile phones and good work

\begin{tabular}{|l|l|l|l|l|l|}
\hline $\begin{array}{c}\text { To produce a } \\
\text { good work }\end{array}$ & $\begin{array}{c}\text { Not at } \\
\text { all }\end{array}$ & $\begin{array}{c}\text { A } \\
\text { little }\end{array}$ & Some & $\begin{array}{c}\text { Quite } \\
\text { a bit }\end{array}$ & $\begin{array}{c}\text { Very } \\
\text { Much }\end{array}$ \\
\hline No of response & 1 & 2 & 13 & 16 & 8 \\
\hline
\end{tabular}

7.4 Mobile to support cooperative work

This section surveyed the ways students use the mobile phones to cooperate and collaborate with each other during course activities. Table (10) shows that above average, the students viewed their mobile phones have allowed and facilitated cooperation among them such as such sharing, exchanging information, developing new ideas and communicating better. 
Table 10. Mobile phone and cooperative work

\begin{tabular}{|c|c|c|}
\hline Cooperative work items & Mean & S. D. \\
\hline Fill the gap for missing information & 3.4 & 1.19 \\
\hline Explain something to someone & 3.8 & 0.97 \\
\hline $\begin{array}{c}\text { Learn different viewpoints from my class } \\
\text { mate }\end{array}$ & 4 & 1.01 \\
\hline Discuss information with my friends/group & 4.1 & 1.24 \\
\hline Correct my understanding/information & 4.1 & 1.01 \\
\hline Find more information from others & 4.13 & 0.91 \\
\hline Share information & 4.18 & 0.96 \\
\hline Exchange information with friends & 4.18 & 1.01 \\
\hline Have new ideas & 4.22 & 0.97 \\
\hline Communicate with the others better & 4.3 & 0.97 \\
\hline
\end{tabular}

\subsection{Problems faced while using Mobile phones}

This question gauged students' perceptions on the some problems facing them while using mobile phones. Table (11) shows that the participants ranged the slow internet connectivity (bandwidth) as the first problem and the lack of available content specifically designed for the course as last problematic.

Table 11. Problems with mobile phones

\begin{tabular}{|c|c|}
\hline Problems items & Ranking \\
\hline Slow internet connectivity (bandwidth). & 1 \\
\hline Inconvenient word input & 2 \\
\hline Hard to use the keyboard & 3 \\
\hline $\begin{array}{c}\text { Charges for mobile connectivity. } \\
\text { Tesigned for the course }\end{array}$ & 5 \\
\hline
\end{tabular}

\section{DISCUSSION}

The picture produced from this case study data seems to indicate that there is a majority of students, who engage in more active roles and cooperative tasks using their mobiles phones during learning activities of the courses. With a good and simple design, it was possible for the students to use their own mobiles into their learning constructing their own knowledge and understanding the course materials with the instructor's guide and support.

\subsection{Mobile phones use in classroom and out classroom}

The ability to use of mobile phone as tools is an important factor when implementing technologies into constructivist approach. It seems that students have used mostly mobile phones to research knowledge and access dictionary. Online dictionaries are considered as cognitive tools helping students to better understanding . Interestingly, there a moderate use of the mobiles by the students to access SULMS and access information that require fast data transfer speed.

\subsection{Mobile phones to promote thinking skills}

One main point can be taken from this exercise results as regards promoting thinking skills. Mobiles have helped the students with their thinking skills, higher ordered thinking and low ordered thinking skills. Though constructivist approach which uses technologies to promotes higher ordered thinking skills. However, the lower ordered thinking skills are not undervalued, here.

\subsection{Mobile to support cooperative work}

Among the other uses of mobiles in this study, was in supporting students' cooperation and collaboration is highly identified. A good explanation for the high use can be put forward. WhatsApp Messenger is available for free; the students send and received multimedia messages and at different length at no cost.

\section{CONCLUSION}

Within Sohar University, it seems that at least in the sample of this study, all students are acquainted with technologies and use them frequently. In this case study, students used their own mobile devices as tools to acquire knowledge enthusiastically. It shows a successful attempt of integrating technologies and constructivist learning approach during the teaching of the CLT course. The students reported mobile phone helped them to manage the course information, to promote more of their thinking skills and to cooperate with each other. This exercise design might be applied by other instructors to integrate technologies into teaching in similar or different situations.

Aim of the study was to show how it is possible to start teaching and learning with the mobile devises. Forty students participated in the students taking a required course. The result of the study gives a good indication for the possibility of integrating technologies into teaching and learning at Sohar University with this simple design. The students have the skills, the devises and confidence of using technologies. However, the study focused on a small group of students taking one academic course and for short period of time. Further studies need to look at the effective use of mobile learning with different courses and to look at the impact of mobile learning on students' performance.

\section{REFERENCES}

[1] B. Alexander," Going nomadic: Mobile learning in higher education," EDUCAUSE Center for Applied Research (ECAR) Bulletin, vol. 2004, no. 16, August 2004.

[2] L. Anderson and Krathwohl D, "A Taxonomy for learning, teaching, and assessing: A revision of Bloom's 
Taxonomy of Educational Objectives". New York: Longman, 2001

[3] M. Ally, "Using Learning Theories to Design Instruction for Mobile Learning Devices," Paper published in the Mobile Learning 2004 International Conference Proceedings, Rome.,2004

[4] C. Quinn, "mlearning: Mobile, wireless, in your pocket learning," Linezine 2000. Retrieved 25 July 2008 from http://linezine.com/2.1/features/cqmmwiyp.htm

[5] E. Strommen,. and B. Lincoln, "Constructivism, technology, and the future of classroom learning," Education and Urban Society, vol. 24, pp. 466-477, 1992.

[6] R Ehrich, F. McCreary, A. Ramsey, R. Reaux and B. Rowland, "Design of technology-based learning environments that support both teachers and students," ERIC Document No. ED 419497. 1998

[7] J. Herrington, A. Herrington, J. Mantei, I. Olney and B. Ferry, "New technologies, new pedagogies: Using mobile technologies to develop new ways of teaching and learning," In J .Herrington, A. Herrington, J. Mantei, I. Olney, \& B. Ferry (Eds.), New technologies, new pedagogies Mobile learning in higher education (pp. 114). Wollongong: University of Wollongong, 2009. Retrieved from http://ro.uow.edu.au/
[8] L. Vygotsky, "Mind in society: The development of higher psychological processes," Cambridge, MA: Harvard University Press, 1978.

[9] K. Campbell, "Effective writing for e-learning environment," Information Science Publishing, Hershey, PA, 2004.

[10] S. Switzer, and N. Csapo, "Survey of student usage of digital technology :Teaching implications. Issues in Information Systems," VI(I), 127-133, 2005.

[11] B. Patten, S. Arnedillo and B. Tangney, "Designing collaborative constructionist and contextual applications for handheld devices," Computers \& Education, 46, 294 308, 2005.

[12] J. Herrington and R. Oliver, "An instructional design framework for authentic learning environments," Educational Technology Research and Development, 48 vol. (3), 23-48, 2000.

[13] B. Riischoff, "Output-oriented language learning with digital media," in M. Thomas, Handbook of Research on Web 2.0 and Second Language Learning, London: Information Science Reference, 42-59, 2009.

[14] D. Jonassen, "Towards a constructivist design model," Educational Technology, 34 vol. 4, 34-37, 1994. 